\title{
Cross-Cultural Alliance-Making and Local Resistance in the Moluccas during the Revolt of Prince Nuku, c. 1780-1810 (PhD Dissertation, Universiteit Leiden, 2007)
}

\author{
Muridan S. Widjojo \\ Center for Political Studies \\ Indonesian Institute of Sciences
}

\section{Introduction}

Fine and rare spices were the primary reason for the Europeans to establish trading posts in Asia. The Dutch took control of the Moluccas at the beginning of the seventeenth century following the establishment of the Dutch East India Company (VOC) in 1602. The use of force and diplomacy to force out their trading rivals - the Spaniards, Portuguese and their allies — was planned and designed from the outset.

How the VOC's power structures were set up in the Spice Islands of eastern Indonesia differed from place to place. In Banda, the region's power structure and organisation of trade and politics was destroyed with the extermination and forced evacuation of the Bandanese population. In Ambon, the VOC established direct rule over an indigenous population that took sixty years to assure. In Ternate, the most important state in the Moluccas at that time, the VOC employed indirect rule; it ruled through the sultans, whom they kept on a short leash by controlling successions and putting their favourites on the throne. 
Conflicts flared from time to time between the Company and Tidore, the second-most important state in the Moluccas, because of Papuan raids and the forced implementation of the spice eradication policy that was imposed in 1667. The Sultan and his grandees tended to undermine the Company directives because they had a stake in condoning and even maintaining the raiding. The spice eradication policy remained a gnawing problem for all parties involved and was particularly burdensome for the local inhabitants who had to render service to the expeditions the Dutch made to enforce the policy. (These expeditions, known as hongi, were punitive incursions to extirpate spice trees.)

From the beginning of the eighteenth century, VOC expeditions were launched regularly to eradicate the raiding, to compel the compliance of the subject people of Tidore, to implement the spice eradication policy and to check for the possibility of intrusion by foreign trade rivals. Despite the concerted efforts of successive Dutch governors, the Sultan of Tidore and his subjects continued their subversive actions but did not openly confront the Company. Two important events, the cession of East Seram to the Dutch in 1768 and the banishment of Sultan Jamaludin in 1779, heralded a new development in the Moluccas: in 1780, Nuku, a Tidoran prince, started one of the longest and most effective revolts against Dutch hegemony in the Moluccas.

The first part of this study explains who Nuku was, why he started the rebellion and how he managed it for more than fifteen years. The secret of Nuku's remarkable staying power can be explained by his masterful handling of alliances.

Consequently, the second part of this paper focuses on the allies who supported the prince's rebellion: the Papuan and Halmaheran raiders, the East Seram traders with their extended networks and, finally, the English East India Company and the English country traders who entered Moluccan waters at the end of the eighteenth century. 


\section{The Rebellion of Prince Nuku of Tidore}

The dispute over the ceding of East Seram triggered the resolute opposition of Prince Nuku. His opposition stiffened when his father and brothers were banished to Batavia. After the attack on Toloa by the Dutch in 1780, Nuku took the lead among prominent Tidoran leaders to revolt. His initial strategies were still inchoate, but he consistently mobilised and recruited increasing numbers of supporters, while maintaining communication with the Tidoran leaders at home.

In 1780 , when the Dutch imposed a new treaty on Tidore, effectively reducing the sultanate to a vassal of the VOC, Nuku created a provisional structure of power as 'the Sultan-in-exile' of Seram and Papua. He did not need much time to drum up forces in the Tidoran peripheries: the Papuans of Raja Ampat, the Gamrange of south-eastern Halmahera and the East Seramese were swiftly coopted. At home, Nuku retained support among the Tidoran grandees. The 'Tempel treachery' and the sudden attack on Gane and Saketa in 1783 is evidence of the success of Nuku's strategies. Moreover, the 'Tidoreesche Revolutie', though premature, showed his success in unifying the rebellious Tidoran forces at home and in exile.

Prince Nuku did not only challenge the Company but also its closest ally on Tidore, the Sultan of Tidore, whose position was challenged by the rebels. Compared to Sultan Patra Alam (r. 1780-83), Sultan Kamaludin (r. 1784-97) turned out to be a formidable opponent, who successfully consolidated his realm and kept the rebels at bay. Around 1790, Nuku's power declined but shortly after he recovered. The support of the North Halmaherans and the return of Raja Ampat and Gamrange adherents was quite decisive in this recovery. During the reign of Kamaludin, Nuku was also supported by the jogugu, the 'prime minister' in the Tidore sultanate, who secretly informed Nuku of the strategy of Sultan Kamaludin and the Dutch. In addition to this, the return of the banished Prince Zainal Abidin from Ceylon in 1794 strengthened Nuku's position even more. Nuku succeeded too in attracting assistance from outside. In 1796, thanks to his cooperation with the English country traders, Nuku's position reached its zenith. That year, 1796, was also the year the Dutch were greatly weakened because of the takeover of Ambon 
and Banda by the English East India Company (EIC). When Nuku's fleet entered the waters of Tidore in 1797, no significant resistance on the part of Sultan Kamaludin was reported.

Prince Nuku now decided that the time had come to implement his goal of unifying all of the Moluccas. Ternate was his most important target but the Dutch fort there was almost impregnable. Since 1796, Nuku coopted Prince Ibrahim of Ternate and even persuaded Sultan Aharal of Ternate to join him. Nuku's goal of defeating the Dutch on Ternate was finally achieved in 1801 thanks to the cooperation of the English. Bacan was also considered significant because it was a part of Nuku's struggle to restore the four kingdoms. As part of that effort, he also 'restored' the Jailolo sultanate. Nuku was a man of great vision. As a North Moluccan leader, his influence spread far beyond the realms of Tidore. He dreamt of Tidore being the most powerful of the four Moluccan kingdoms and that it would form the backbone of a state independent of foreign powers.

Even though Nuku, in alliance with the English forces, managed to conquer the Ternate sultanate and Fort Oranje, his goal of controlling Ternate was never realised nor was his dream of uniting the Moluccas. The Treaty of Amiens in 1802 restored the authority of the Dutch in the Moluccas and annulled the treaty between Nuku and the English Resident. Nevertheless, Nuku remained confident of his power even during his last days in late 1805 . He retained his independent attitude to the Dutch until his last breath.

Nuku's successor, Zainal Abidin (r. 1806-10), was a weak man. As a Sultan, he was not a powerful and visionary figure who would gain the respect of other leaders. His greatest weakness was his selfishness and consequently he could not retain the loyalty of his followers. His political principles were ambiguous and he was indecisive. When dealing with the Dutch, his stance was never bold and he had no clear strategy. The English support for Tidore, which continued until his death in 1810, failed to be exploited. His biggest failing was his ignorance of the political developments in the relations between the English and the Dutch. He failed to control his realm. 


\section{Nuku's Papuan Allies and their Raiding System}

The raiding parties of Papuan islanders and Halmaherans had been active before the arrival of the Europeans in the Moluccas in the sixteenth century. Their raiding had its roots in the customs of the communities and functioned, in a sense, as a de facto trading system using extortion. In the sixteenth century, the goal of raiding was to capture people and to release them in exchange for redemption money. If the captives were not redeemed, they would be killed. This pattern changed from the early seventeenth century onwards. Those captives who were not redeemed were, if male, employed as slave labour and, if female, taken home as wives. (The Banda nutmeg plantations were always in need of slaves.) The areas of the west coast of New Guinea, Onin and Kobiai, as well as Raja Ampat and its surroundings, were important sources for slaves. This also motivated the raiding activities.

Despite the limited economic value and the dangers involved in raiding, many raiders continued their violent occupation. These overseas ventures also allowed the Papuans and the Halmaherans to accumulate foreign goods that did not only have economic value but also politicocultural significance. Foreign goods acquired an important function in the ceremonial exchange of presents, for payment of fines, bride wealth and other ceremonial exchanges. In this way, raiding was also seen as gathering foreign power. The raiders and the goods they acquired were treated as subjects and objects imbued with the magical power of the foreign world. For the raiding groups, Tidore was seen as the source of foreign power. In other words, those who had acquired or possessed these foreign goods by raiding enjoyed prestige, authority and power, which allowed them to dominate their community.

During the rebellion of Prince Nuku, the raiding changed in pattern, style and aim; there was a political element added. The targets of the attack were selected with more care. Raiders now attacked areas and people perceived to be Dutch subjects and allies and attacked even those who declined to join or support the rebellion. By supporting the rebellion, Papuan and Halmaheran raiders contributed significantly to strengthening Prince Nuku's rebel bands. During the rebellion, 
the trading and raiding fleets of the Papuans were transformed into a formidable naval and military force of Prince Nuku.

\section{Nuku's East Seramese Allies and their Trading Networks}

From the sixteenth century, trade created a class of wealthy East Seramese merchants. The traders produced sago bread and traded it for nutmeg and mace in Banda. They linked the westward trading networks such as Timor (sandal wood), Bali (slaves, cloth), Bima (gold), Java (rice), and Sulawesi with their eastward trading networks around MacCluer Gulf (massoy bark and slaves) and Raja Ampat. They enjoyed relative prosperity at that time. When the Dutch imposed a monopoly system on spices, the Seramese were deprived of their most lucrative trading goods. The limitations of navigation hampered a great deal of their westward and eastward trading networks. To enforce its rules, the Company established contracts, often after violent encounters but, in the long run, those contracts were not readily complied with.

The hongi expeditions, the most violent method of intimidation used by the Dutch, were an instrument of surveillance and repression aimed at the Seramese in general. The East Seramese were regular targets of the hongi raids and many were chased and killed. Their houses and vessels were burnt, their cash crops were uprooted and most of their wealth looted by the warriors of the hongi. Almost nothing was left after a punitive expedition had been by, except for whatever had been hidden in the forest or the valuables they carried with them during the escape. The survivors had to start their lives again from scratch. For two centuries in a row, the East Seramese suffered impoverishment as a result.

The East Seramese managed to keep trading because they continued to cooperate with other traders mainly from Macassar. Often the vessels and the trading items were lent by Macassarese. The East Seramese functioned as brokers and they maintained traditional trading networks, especially for the eastern trade, such as the New Guinea coasts and Raja Ampat Islands. The Dutch, it seems, never possessed enough power to terminate the Seramese trading networks. It would have been very 
expensive to do so, especially in the second half of the eighteenth century as VOC power declined. Dutch control became even weaker when Prince Nuku moved into the area with his followers and encouraged the East Seramese to join the rebellion.

In many ways, East Seram was independent of Tidore. With or without Tidore, the East Seramese continued to maintain their trading networks. From the scattered evidence available, it can be concluded that relations between East Seram and Tidore were flourishing during the rebellion of Prince Nuku. Most of the prominent kapiten laut [sea captains] of Nuku were East Seramese traders. We can only find two East Seramese leaders: Kapiten Baukan and Orangkaya Kana-Kana, who persisted with their support of the Company. Prince Nuku's presence on East Seram encouraged and protected the indigenous trading networks that had been threatened for a long time; the network of the East Seramese who had long been living in 'enmity' with the VOC was one such trading network. Using Waru as his headquarters, Nuku and his forces could effectively attract the support of the East Seramese and threaten those who declined to cooperate.

\section{The English East India Company and the English Country Traders as Allies}

From the end of the seventeenth century, the English again and again tried to obtain spices from the Moluccas and Papua. However, only in the second half of the eighteenth century did they intensify their efforts, which were stimulated by the growing demand for products from Southeast Asia that could be used for payment in place of silver for their increasing purchases of silk and tea from Canton. In 1774, an English trader, Thomas Forrest, succeeded in travelling around Raja Ampat and Northwest New Guinea. He collected spices and had some contact with Sultan Bacan and Sultan Tidore.

Except for the Sultan of Ternate, Moluccan rulers tended to welcome the English as their allies. Sultan Jamaludin of Tidore himself wrote a letter to Thomas Forrest and offered an alliance. Prince Nuku, 
Jamaludin's father, was determined to seek an alliance with the English. His saving the lives of an English country traders' crew in 1783 was a great investment in building friendship with the English. His envoys to Bengkulu in 1784 and to Bengal in 1785 were treated with honour and cordiality. In 1796, the British Governor-General decided to supply Prince Nuku with guns and ammunition.

Prince Nuku managed to build a strong reputation on the basis of his good will and cooperation with the English. The contact between Prince Nuku and the English, chiefly with the country traders, was one of the decisive factors in his success in maintaining his struggle for more than twenty years. Prince Nuku even took advantage of the intervention of English forces when their presence was still a rumour. He manipulated the fear of the Dutch and sent fake reports through local spies who reported to the Dutch government at Ternate, Ambon or Banda. By keeping the rumour about the arrival of the English forces alive, he kept the morale of his supporters high.

Mutual and active cooperation between Prince Nuku's forces and the English country traders intensified in 1795. Subsequently, great amounts of spices were traded in return for great quantities of guns and ammunitions. The English country traders also carried Nuku's envoys to Bengal in 1796. The increased supply of weapons improved decisively the fighting power of Prince Nuku. As a consequence, the support of the local leaders and communities grew even more. The seizure of Bacan and the takeover of Tidore in 1797 was the result of the cooperation between Prince Nuku and the English traders.

Concerning the affairs of Tidore, the English had no considered policy. Their ignorance of Moluccan internal politics allowed the local residents in the Moluccas to develop a policy based on their own preferences. However, when the English dealt with wider political matters, their policies were determined by their larger interests in European diplomacy, chiefly in terms of their rivalry with the French. If the European theatre made it possible to win the Dutch from the French camp, the English were prepared to make concessions to them elsewhere in the world, for example, in Southeast Asia. 
During the English occupation, the Tidorans and Nuku found that the English East India Company (EIC) also behaved as a colonial overlord. The English continued the claim of the Dutch in having monopoly rights to the trade in spices. This led to conflicts of interest between the English Resident and with Sultan Nuku and the East Seramese. The forces the English had at their disposal were not sufficient to prevent the smuggling by the people at the centres of production who co-operated with the traders of East Seram and the Tidoran elite. To make it more difficult, the EIC officials also had to deal with the English traders who had good relations with the traders not only in East Seram but also in Halmahera and Raja Ampat. These country traders had also the support of some senior officials in the East India Company. The English East India Company strove to have Nuku provide cloves for a fixed price but Nuku would eagerly break the agreement when he could strike a deal with the country traders who were ready to purchase the cloves at a higher price.

The policy of Resident Farquhar to reduce the position of Ternate and to conclude a treaty with Sultan Nuku was the greatest victory Nuku achieved during the presence of the English. Tidore was referred to as an ally, not as a vassal. Politically, Tidore enjoyed independence and a superior position to Ternate. This had not been so for a long time during Dutch rule. Moreover, the treaties, which the Tidoran sultanate had concluded in the past with the Dutch, were annulled. In return, the British Government had the monopoly rights. Unfortunately, this treaty was dissolved by the British Government in India in 1802. In the end, the story about the relations between Prince Nuku and the British Government tragically showed the lack of power of small states in Southeast Asia vis-à-vis European intruders. 